\title{
SOME REMARKS ON THE FORMATION OF SCRATCH CIRCLES ON WIND-BLOWN SAND
}

\author{
MAT'tI SEPpäLÄ
}

\begin{abstract}
SEPPÄLÄ, MATt'T 1972: Some remarks on the formation of scratch circles on wind-blown sand. Bull. Geol. Soc. Finland 44, 131-132.

The present paper provides a report of the formation of scratch circles on drift sands during the deposition and deflation phases of sand dune formation. Observations were carried out on dune fields in western Finland, central and southwestern Sweden.
\end{abstract}

Matti Seppälä, Department of Geography, University of Turku, SF-20500 Turku 50, Finland.

Recently scholars have devoted attention to the formation of scratch circles (Scharrkreise) (Kukal \& Al-Naqash 1970, Koerfer \& Schwarzbach 1971). The observations made of the microforms found on the surfaces of eolian sands described here were carried out on the Kalajoki beach dunes in western Finland $\left(64^{\circ} 14^{\prime} \mathrm{N}\right.$, $23^{\circ} 49^{\prime} \mathrm{E}$ ) in 1965 , on the Mora postglacial dune field in central Sweden $\left(61^{\circ} 03^{\prime} \mathrm{N}, 14^{\circ} 27^{\prime} \mathrm{E}\right)$ in 1971 , and on the Halmstad beach dunes $\left(56^{\circ} 37^{\prime} \mathrm{N}\right.$, $\left.12^{\circ} 54^{\prime} \mathrm{E}\right)$, southwestern Sweden in 1971.

These observations show that scratch circles are formed at different phases of dune development: 1) during the deposition phase and 2) during the deflation phase.

As the sand is deposited round the roots of different types of grass the leaves of the plants come into contact with the sand and etch circles on the surface of the sand. The dried-up lower leaves of the plants (couch grasses) function in the same way. In this way small scratch circles were formed on small reaccumulation banks about half a metre high in the Mora dune field and on accumulation areas of active beach dunes on the southwestern coast of Sweden. From the picture published by Koerfer \& Schwarzbach (1971) it is clear that scratch circles in Iceland were formed in the same way, too. In the Mora area it has been Triticum repens and in Halmstad region Elymus arenarius and some other couch grasses which have caused the scratch circles.

When sand is blown away from the ridge of the dune by strong winds the roots of plants on the dune are laid bare and the plants collapse on to the surface of the sand. The wind then blows the plants around their roots so that a circle is described in much the same way as one might draw a circle using a pair of drawing compasses. The scratch circles found on the Kalajoki beach dunes have been formed in this way (Fig. 1). In 


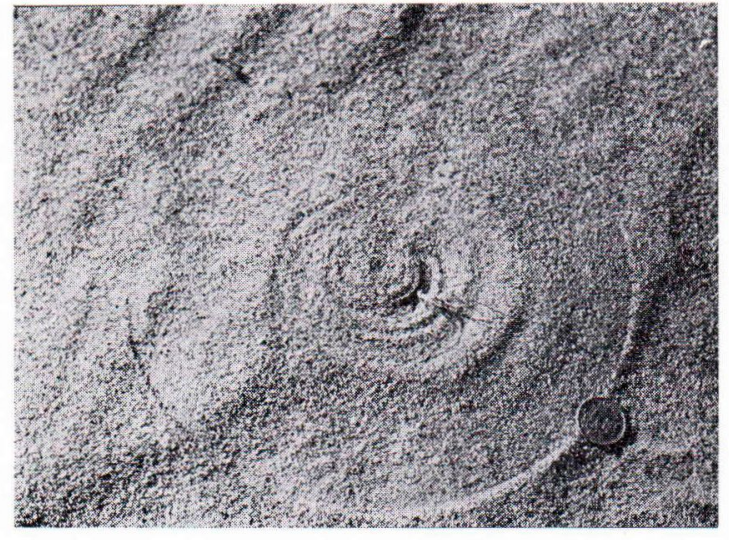

FIG. 1. A scratch circle formed during the deflation phase on a beach dune in Kalajoki area. The collapsed grass (Festuca ovina) lies on the surface. Wind blows from the upper left corner of the picture. Diameter of the coin is

$22 \mathrm{~mm}$. Photographs by the author. July 2, 1965.

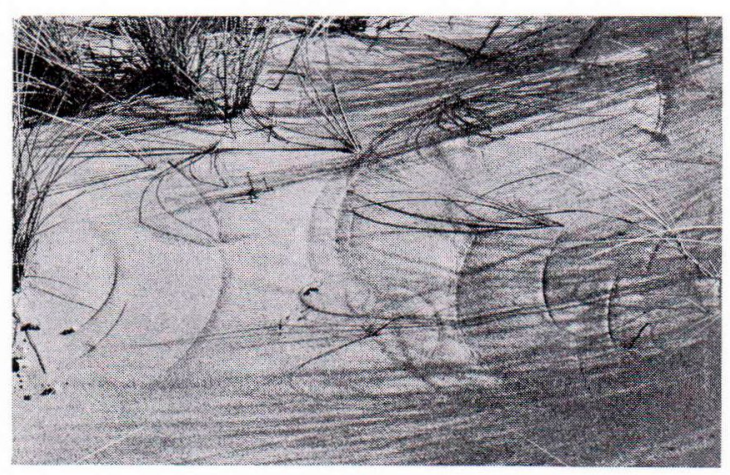

FIG. 2. Scratch semicircles formed on the deposition surface of a beach dune near Halmstad. Half circles on the sides of the grasses. Photographed in the wind direction. November 4, 1971.

this case the plants causing the circles were Festuca ovina and Elymus arenarius.

The diameter of the circles varied between 10 and $40 \mathrm{~cm}$. Some of them only half circles while others were almost complete circles or, in some cases, closed circles. The direction of the wind did not vary during the time they were formed but variations in the strength of the wind and its persistence, or blusteriness, caused closed circles to be formed. The circles were deeper on the lee side of plants so that it is possible to draw conclusions as to direction of the wind from the details of the circles just as was surmised by Kukal \& Al-Naqash (1970, p. 334). However, near Halmstad was observed that the leaves of some couch grasses draw half circles on both sides of the plants (Fig. 2).

In cases of Kalajoki and Mora the surface of the sand was quite dry. In Halmstad scratch circles formed on the surface of wet sand. One precondition required for the formation of scratch circles is doubtless the existence of a sufficiently sparse covering of vegetation, so that the wind can easily blow the plants around their axis ( $c f$. Langerfeldt 1935, p. 460).

It is certainly possible to find fossilised scratch circles in sandstone. In such a case it is necessary to bear in mind the circumstances in which the sand was accumulated when determining whether they might have been formed beneath water as has been reported by Langerfeldt (1935).

Acknowledgements - The author wishes to thank Professors A ke Sundborg and John O. Norrman, Uppsala, for their kindly guidance during the excursions in Sweden. Financially the author was supported by the FinnishSwedish Cultural Foundation and the National Research Council for Natural Sciences, Finland.

\section{REFERENCES}

Koerfer, L. E. \& Schwarzbach, M. (1971) Scratch circles in Iceland. Zeitschrift für Geomorphologie 15, 348-349.

Kukal, Z. \& Al-NaqAsh, A. B. (1970) Scratch circles on the Pliocene sandstones in Central Iraq. Zeitschrift für Geomorphologie 14, 329-334.

LANGERFELDT, F. (1935) Untermeerische Scharrkreise im Schlick. Natur und Volk 65, 458-461.

Manuscript received, February 14, 1972. 